\title{
INFLUENCE OF SELECTED FACTORS ON IMPLEMENTATION OF THE PPP PROJECTS IN TRANSPORT
}

\author{
Beata Zagożdżon*, Andrzej Rogowski \\ Faculty of Transport, Electrical Engineering and Computer Science, Kazimierz Pulaski University of Technology \\ and Humanities in Radom, Radom, Poland \\ *E-mail of corresponding author: b.zagozdzon@uthrad.pl
}

\begin{abstract}
Resume
Countries seek to use the knowledge and capital of the private sector to minimise the gap between the transport infrastructure needs and the capacity of their budgets. A form of private investor involvement is usually a public-private partnership PPP. However, success in implementing the PPP projects requires appropriate economic, legal and institutional conditions.

The article presents results of research aimed at identifying the PPP success factors in Poland and assessing the strength of impact of individual factors on the implementation of projects. An analysis of the subject literature was carried out, based on which the success factors were determined. Next, econometric modelling methods were applied (correlation and regression), which were used to measure the degree of correlation between the variables and showed the relationships of variables to each other.
\end{abstract}

Available online: https://doi.org/10.26552/com.C.2021.1.A14-A20

\section{Article info}

Received 30 March 2020

Accepted 15 May 2020

Online 23 October 2020

\section{Keywords:}

critical success factors for PPP,

transport,

PPP in Poland

ISSN 1335-4205 (print version)

ISSN 2585-7878 (online version)

\section{Introduction}

Public-private partnership (PPP) as a form of cooperation between the public and private partners, who act together while realizing a project, keeping their own goals and interests, has been an area of scientific research since the 1980s. Initially, directions of this research included such issues as: risk management, managing relations between project partners, project financing system or public procurement procedures. However, the global financial crisis in 2007-2008 intensified the research of scientists on the PPP issues. Governments around the world are trying to use the knowledge and capital of the private sector to minimize the gap between the needs for infrastructure, especially transport and possibilities of their budgets. The subject of particular interest of governments is the transport infrastructure, which determines economic and social development, and in the current state of quantity and quality requires large investment outlays. These include European rail, road and air transport systems, as well as urban transport systems, which are suffering from effects of congestion and citizens expect a rapid improvement of current transport systems. At the same time, the previous practice of the PPP implementation and the conducted research have shown that the success of a partnership requires appropriate economic, legal, institutional and social conditions. Therefore, at present, the main area of research on the PPP is to identify success factors and determine influence of particular factors, their strength of influence on the process of successful project implementation [1]. Result of this research is to determine the best ways of planning and realizing the PPP investment projects.

The aim of the undertaken research was to identify the success factors of the PPP in Poland and to assess the strength of influence of particular factors on implementation of projects. The notion of success is understood very synthetically (because it is not the main subject of research) and means of a PPP project that was performed in accordance with the budget, schedule and service quality standard. The adopted aim of the research implied in the first stage - a review of the subject literature and then - developing statistical data and applying econometric modelling methods. A qualitative research approach was used, based on conceptual and comparative analysis of the secondary data, scientific literature and reports of international institutions. Then, in the next stage of research, correlation and regression analysis were applied. The former was used to measure the degree of correlation between the variables and the latter showed the quantitative dependence of one variable on another.

\section{Background of the PPPs}

As a result of the financial crisis in the 1980s, governments have focused their attention on the private sector as a source of financing for investments of general interest. One of the first scientists who dealt with this 
issue was a professor at Columbia University - E. S. Savas [2-3]. Research concerning not only the financing, but the operation and management of public infrastructure by the private sector as well, was conducted in the 1990s by D. Osborne and T. Gaebler [4]. Among European countries, the United Kingdom implemented various forms of cooperation between the public and private sector at the earliest and the largest scale. On the initiative of the government agency - The Private Finance Initiative, a lot of theoretical and research work on the role of the private sector in the sphere of public infrastructure and services was created [5-7]. Initially, the research directions covered such issues as: risk management, management of relations between the project partners, project financing system or public procurement procedures. However, in the last twenty years the main area of research are the success factors of the PPP, described in the literature as critical success factors (CSF). Their detailed review was presented by the author in an earlier publication [8], therefore only the most important of them will be discussed here.

Based on the literature research, it can be assumed that classification of determinants of the PPP success includes four groups of factors: economic and financial, political and legal, technical and social. Moreover, they can be divided according to the level of analysis. Determinants that are shaped by the government and its institutions can be defined as factors at the macro level. On the other hand, those that affect practical implementation at the stage of project preparation and feasibility assessment concern the micro-level.

The research undertaken has focused on the macrolevel factors as they provide a fundamental framework for functioning of the partnership. Without them the PPP formula will not exist at all, let alone successful implementation. Thus, the research conducted by Chou et al. [9] shows that at the macro level the following factors have the strongest impact: stable macroeconomic conditions, economic and political support of the government, legal system, availability of financing, competent advisory public agencies, social support, transparent procurement process, competition in the procurement process. Osei-Kyei and Chan [1] also point out in their research the importance of stable macroeconomic conditions, a favourable legal framework, political and social support and a clear procurement system. In general, the conducted research shows that the PPPs are more common in countries where there are strong and effective legal institutions and in countries where legal regulations well protect investors' rights [10]. All this creates a good atmosphere for investors and has a positive impact on trust between the government and the private consortium. Mutual trust is important for success of the PPPs [11].

Moreover, the already mentioned studies by Osei-Kyei and Chan [1], underline the importance of factors such as the appropriate allocation and sharing of risks and presence of the strong private consortia on the economic market. According to studies, undertaken by Esmaeili, Pellicer and Molenaar [12], the following factors proved to be the most important: a strong private consortium, appropriate risk allocation and available financial market.

Out of these factors, the most important for the transport infrastructure projects, as highlighted by Hammami et al. [10] and Chou et al. [9], is the country's stable macroeconomic condition and, in particular, such indicators as: the GDP level and growth, market size, customer purchasing power. Good macroeconomic conditions, according to Mansoor and Klein [13], are able to attract investors and increase the level of financial resources. In contrast, the size of the market affects the volume of demand and the purchasing power of customers at the level of future fees, which, in turn, determines the revenues and liquidity of the private consortium. Efficient financial intermediation, free access to capital and financial services are also important factors. Involvement of multilateral lenders and credit agencies in the transport project strengthens the positive outcome of this investment [14]. The factor related to the government's economic policy and legal system is the transparent (transparent) public procurement process and the level of competitiveness of the procurement market. Intensity of competition means a large number of complex bids, which gives the possibility to choose a better supplier and carry out an ex-ante evaluation.

The conceptual and comparative analysis of the scientific literature has allowed identification of the critical success factors for the PPP projects that will be further investigated. These included: macroeconomic conditions, the legal framework (including the level of democracy and corruption) and availability of funding and competitiveness of the public procurement system.

\section{$3 \quad$ Methodology and research results}

The tests carried out consisted of two main stages:

- in the first stage, the critical success factors for the PPPs were assigned macroeconomic quantities and the quantitative indicators that are appropriate for them, characterize them, constitute an aggregated set of information; these quantities were established based on the statistical data and reports of international institutions and covered the period 2009-2018,

- in the second stage, the correlation and regression analyses were used and the constructed models made it possible to measure the degree of correlation between the variables and interdependencies occurring between them.

Thus, in order to characterise the macro-economic conditions, the basic macro-economic quantities, expressed in monetary terms, were selected: gross domestic product - GDP, exports, deficit, public debt. The international investment position of a country, which indicates whether a given country is a creditor or a net debtor to the foreign country, was also taken into account [15]. Positive values show that the country is a creditor and negative values - a debtor. This indicator is presented both in monetary units, as well as in relation to GDP, because the preliminary 
Table 1 Indicators (explanatory variables) included in the surveys

\begin{tabular}{cr}
\hline a group of success factors & indicators \\
\hline $\begin{array}{c}\text { macroeconomic conditions } \\
\text { availability of financing }\end{array}$ & gross domestic product GDP, exports, deficit, public debt, international investment position (EUR \\
billion), international investment position (\% of GDP) \\
legal framework, level of \\
$\begin{array}{c}\text { democracy } \\
\text { competitiveness of the }\end{array}$ \\
public procurement process
\end{tabular}

studies have shown its great influence on success of the PPP projects.

The rule of law indicator was used to assess the legal regulations and the general level of standards of operation of the state and its institutions (scale from 0 to 1 ; where 1 means the strongest compliance with the rule of law) [16], democracy (scale from 0 to 10; where 10 means a fully democratic state) [17] and a corruption indicator [18]. The latter shows how national entrepreneurs assess the level of corruption in the public sector. The indicator value of 0 means the highest level of corruption and 100 means the lowest level of corruption.

Another group of indicators allows assessing availability of financing. The following indicators were taken into account: bank assets, debt and private sector credit. The first one, due to its importance for the successful implementation of the PPP projects, is presented in EUR billion and in \% of the GDP. The other two, however, are presented only in \% of the GDP [15]. Debt of the private sector is the state of liabilities of enterprises, households and non-commercial institutions acting for the benefit of households, calculated cumulatively in subsequent years. Private sector credit is the net amount of liabilities of private entities, incurred in a given year.

The competitiveness of the public procurement process was assessed by means of an indicator that reflects several aspects of public procurement, including competition and red tape. The indicator measures the percentage of contracts awarded for which there was only one bidder [19]. A larger number of bidders is more advantageous because it means that public purchasers have more options and can obtain the better value for the money.

Table 1 summarises indicators that have been assigned to each PPP success factor.

In the second stage of research, the correlation and regression analyses was used. The first is used to measure the degree of correlation between the variables. The regression analysis is an extension of the analysis, which allows for a quantitative description of a relationship between one variable and another. The subject of the research was the degree of connection between the value and number of the PPP agreements concluded in a given year and indicators assigned to particular groups of the PPP success factors (Table 1). The two econometric (regression) models are given, expressing the value of agreements (Wu) and number of the PPP agreements $(\mathrm{Lu})$ concluded in a given year. Calculations were made in an Excel spreadsheet. Selected regression models are presented in Table 2 and in Figures 1 and 2. Next, the linear correlation coefficients, Spearman's RHO (RHO Spearman) and linear regression functions were determined (Table 3).

It is worth noting that in the case of number of models estimating the number of the PPP agreements, the adjustment measured by the coefficient of determination $\mathrm{R} 2$ is much better than in the case of agreement values. Both models Wu1 and Wu2 are models of generalised log-hyperbolic regression; Lu1 is a model of exponential regression and Lu2 of hyperbolic regression. It is important to note that the best suited contract count models are those with six and five explanatory variables (indicators), contract count models use seven indicators. The average annual value of the PPP contracts in Poland in the years 2009-2018 amounted to 0.1405 billion Euro (standard deviation 0.1384 billion Euro) and the average number of contracts 13.1 (standard deviation $=5.7$ ). Thus, the average error in estimating the value of contracts, according to the given models, represents for Wu1 20.7\% and Wu2 21.4\% of the average value of contracts and for Lu1 $4.0 \%$ and Lu2 $4.5 \%$ of the average number of contracts.

There is a significant positive correlation between the GDP, value of exports, level of public debt and a negative correlation between the international investment position and the deficit and number of contracts concluded. In the case of the value of contracts, the correlation with these macroeconomic indicators is much weaker. Level of the GDP value indicates the size, potential of the internal market that generates demand. This is an important factor for possible charges for use of the transport infrastructure. Correlation coefficients also show that growth of the GDP and value of export, i.e. generally the economic development of the country, causes an increase in number of the PPP agreements. On the other hand, a deterioration of the international position, i.e. an increase in the country's debt to foreign countries, results in an increase in both the number and value of concluded agreements. In addition, an increase in the public debt level positively influences an increase in the number of agreements. Based on that, one can formulate an assumption that an increase in the level of debt, i.e. generally the government's willingness to take on obligations and then an increase in money supply in the economy, contributes to development of the PPP, both in terms of the number of concluded agreements and their value. However, it is a conclusion that requires even further, in-depth research and analysis. Undoubtedly, however, 
Table 2 Selected econometric models (regression) of the PPP agreements concluded in a given year in years 2009-2018 in Poland: Wu value of agreements [billion EUR], Lu number of agreements

\begin{tabular}{|c|c|c|c|c|c|}
\hline W & equation & $\mathrm{R}^{2}$ & $\begin{array}{c}\bar{x}_{d} \\
(\mathrm{bln} \\
\mathrm{EUR})\end{array}$ & $\begin{array}{c}s_{d} \\
(\mathrm{bln} \\
\mathrm{EUR})\end{array}$ & $\begin{array}{l}\frac{s_{d}}{\bar{x}} \\
(\%)\end{array}$ \\
\hline Wu1 & $\begin{array}{c}\hat{y}=\exp \left(\frac{38111.33}{x_{9}}-\frac{5158.27}{x_{9}}-\frac{3608.38}{x_{6}}+\frac{16549.21}{x_{5}}+\frac{481.79}{x_{4}}-\right. \\
\left.-\frac{1199.27}{x_{2}}-27.8616\right)\end{array}$ & 0.8908 & 0.02904 & 0.03724 & 128.2 \\
\hline Wu2 & $\hat{y}=\exp \left(\frac{36115.2}{x_{9}}-\frac{5128.85}{x_{9}}-\frac{3539.19}{x_{6}}+\frac{16185.69}{x_{5}}+\frac{636.52}{x_{2}}-24.3909\right)$ & 0.8822 & 0.03000 & 0.03879 & 129.3 \\
\hline Lu1 & $\begin{aligned} \hat{y}=\exp ( & 0.18542 x_{13}-0.08103 x_{9}+0.26490 x_{8}-1.37281 x_{6}-0.37548 x_{5}+ \\
& \left.+0.00565 x_{4}-0.08754 x_{2}+6.36924\right)\end{aligned}$ & 0.9874 & 0.52 & 0.40 & 77.7 \\
\hline Lu2 & $\begin{aligned} \hat{y}= & \frac{0.09056}{x_{13}}-\frac{0.22300}{x_{9}}-\frac{0.83611}{x_{8}}+\frac{3.18745}{x_{6}}-\frac{0.91355}{x_{5}}+\frac{0.04327}{x_{4}}- \\
& -\frac{0.18879}{x_{2}}+6.50\end{aligned}$ & 0.9847 & 0.59 & 0.42 & 71.4 \\
\hline
\end{tabular}

$W$ - specification

$\bar{x}_{d}=\frac{1}{n} \sum_{i=1}^{n}\left|y_{i}-\hat{y}_{i}\right|$ - mean absolute deviation of model values from actual values, where $y_{i}$ actual value, $\hat{y}_{i}$ model value (regression function),

$s_{d}$ - standard deviation of the absolute deviation of model values from actual values,

$R^{2}$ - determination factor,

$x_{i}$ - explanatory variables, according to the Table 3.

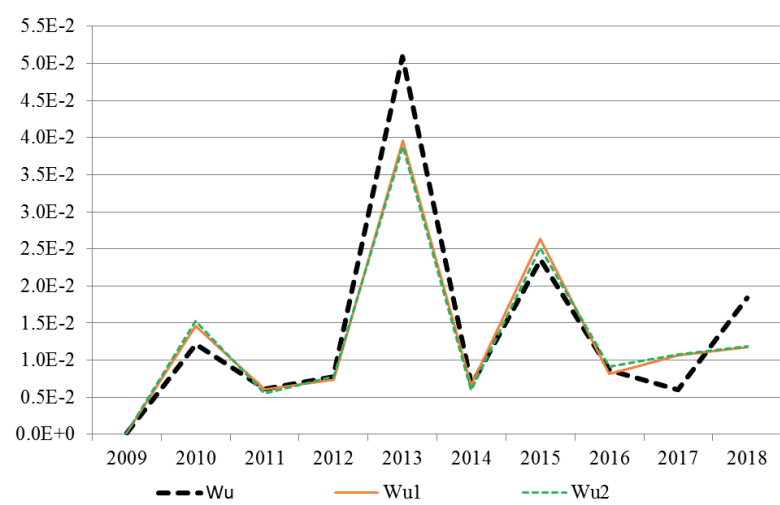

Figure 1 Value of the PPP agreements in Poland in 20092018 and their estimation with regression models Wu1 and Wu2 from Table 2

the increase in the budget deficit in a given year limits the number of concluded agreements. In the case of other indicators, the correlation is at most very weak.

There is a strong correlation between the rule of law and number of the PPP agreements concluded. Stable, clear regulations and compliance with the law are the factors that have the greatest impact on development of the PPP projects. In the case of the influence of this factor on the value of concluded agreements, one can only speak of a weak linear correlation. The value of the correlation coefficient for the number of contracts, which is 0.78 , indicates a very strong correlation, which in practice means a large increase in number of contracts with a low level of corruption. Impact of this factor on value of contracts can be described as relatively weak, although significantly stronger than the rule of law. Nevertheless, the low level of corruption contributes to the value of contracts. The level

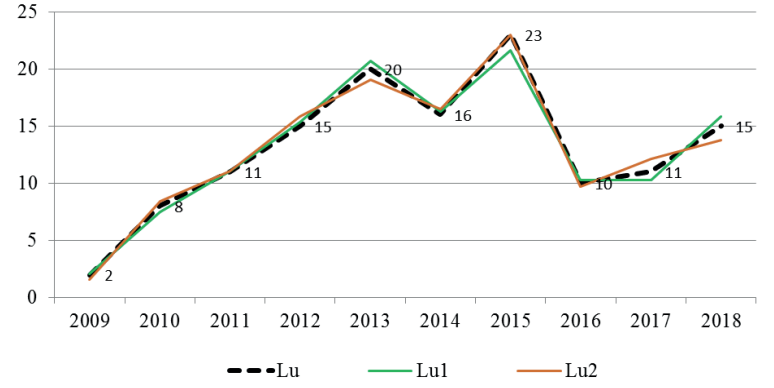

Figure 2 Number of the PPP agreements in Poland in 2009 2018 and their estimation with regression models Lu1 and Lu2 from Table 2

of democracy, on the other hand, can be considered a very insignificant factor for the PPP projects.

There is a significant correlation between the level of financial assets of banks and the number of concluded PPP agreements - an increase in assets also in relation to the GDP, causes an increase in number of agreements. However, the level of private sector debt has the greatest impact, among the financial instruments taken into account. A progressive increase in the private sector debt implies an increase in the number of concluded agreements. On the other hand, credit flows of the private sector in a given year clearly influence, primarily the value of concluded agreements and, to a lesser extent, their number. It is a negative correlation - an increase in the level of private sector credit liabilities in a given year limits the value of concluded PPP agreements to a greater extent than the number of projects. 
Table 3 Linear correlation coefficient, Spearman's rank correlation coefficient, directional coefficient and linear regression $(y=a x+b)$

\begin{tabular}{|c|c|c|c|c|c|c|c|}
\hline \multirow{2}{*}{\multicolumn{2}{|c|}{ specification }} & \multicolumn{2}{|c|}{ linear correlation factor } & \multicolumn{2}{|c|}{$\begin{array}{c}\text { spearman's rank correlation } \\
\text { factor }\end{array}$} & \multicolumn{2}{|c|}{$\begin{array}{c}\text { linear regression directional } \\
\text { factor } a \\
(y=a x+b)\end{array}$} \\
\hline & & $\begin{array}{l}\text { value of } \\
\text { contracts } \\
\text { concluded in } \\
\text { a given year } \\
\text { (Wu) }\end{array}$ & $\begin{array}{l}\text { number of } \\
\text { contracts } \\
\text { concluded in } \\
\text { a given year } \\
\text { (Lu) }\end{array}$ & $\begin{array}{l}\text { value of } \\
\text { contracts } \\
\text { concluded in } \\
\text { a given year } \\
\text { (Wu) }\end{array}$ & $\begin{array}{l}\text { number of } \\
\text { contracts } \\
\text { concluded in } \\
\text { a given year } \\
\text { (Lu) }\end{array}$ & $\begin{array}{l}\text { value of } \\
\text { contracts } \\
\text { concluded in } \\
\text { a given year } \\
\text { (Wu) }\end{array}$ & $\begin{array}{l}\text { number of } \\
\text { contracts } \\
\text { concluded in } \\
\text { a given year } \\
\text { (Lu) }\end{array}$ \\
\hline 1 & GDP & 0.1789 & 0.4980 & 0.3333 & 0.5061 & 0.00051 & 0.05860 \\
\hline 2 & exports & 0.1816 & 0.4913 & 0.2970 & 0.4207 & 0.00069 & 0.07751 \\
\hline 3 & deficit & -0.1110 & -0.4302 & -0.1758 & -0.3598 & -0.00222 & -0.35650 \\
\hline 4 & public debt & 0.3571 & 0.5341 & 0.3697 & 0.3476 & 0.00218 & 0.13500 \\
\hline 5 & $\begin{array}{l}\text { international investment } \\
\text { position (EUR billion) }\end{array}$ & -0.2475 & -0.5066 & -0.2606 & -0.4268 & -0.00154 & -0.13031 \\
\hline 6 & $\begin{array}{l}\text { international investment } \\
\text { position (\%GDP) }\end{array}$ & -0.3860 & -0.4501 & -0.3455 & -0.4573 & -0.02919 & -1.41120 \\
\hline 7 & private sector credit & -0.4493 & -0.3244 & -0.3222 & -0.2844 & -0.05884 & -1.76102 \\
\hline 8 & private sector debt & 0.2115 & 0.5989 & 0.3212 & 0.5061 & 0.00614 & 0.72089 \\
\hline 9 & $\begin{array}{l}\text { bank assets (EUR } \\
\text { billion) }\end{array}$ & 0.1609 & 0.5016 & 0.2970 & 0.4207 & 0.00039 & 0.04970 \\
\hline 10 & bank assets (\%GDP) & 0.1447 & 0.5272 & 0.2606 & 0.3354 & 0.00437 & 0.66030 \\
\hline 11 & democracy & -0.0594 & 0.0047 & -0.2646 & 0.1238 & -0.03378 & 0.11148 \\
\hline 12 & rule of law & 0.2849 & 0.6670 & 0.3084 & 0.7187 & 1.64243 & 159.375 \\
\hline 13 & corruption & 0.3874 & 0.7848 & 0.4602 & 0.6543 & 0.01342 & 1.12657 \\
\hline 14 & $\begin{array}{l}\text { competitiveness of the } \\
\text { public procurement }\end{array}$ & -0.0285 & 0.1175 & -0.1184 & 0.1442 & -0.17826 & 30.4704 \\
\hline
\end{tabular}

The last of the examined factors - competitiveness of the public procurement market in practice has no impact on number of concluded contracts and value of those contracts.

The Spearman's rank correlation coefficient shows that a positive moderate correlation appears between the size of the GDP, level of exports, private sector debt and assets of banks. A moderate negative correlation occurs in the case of international investment position and number of contracts. On the other hand, when analysing the strength of the correlation between the value of contracts and individual characteristics, one should pay attention to the significant correlation with corruption. The strength of the correlation between the other features is low.

Analysis of the directional coefficient and linear regression allows formulating a conclusion that appropriate legal regulations and observance of the rule of law can have a very significant influence on increase in number of the PPP agreements. An analogous situation, however, the expected changes will not be so decisive, occurs in the case of increasing competitiveness of the public procurement market. Important factors are also private sector credit commitments in a given year and the international investment position of the country. An increase in credit debt may cause a decrease in number of agreements concluded in a given year. The opposite situation occurs when the investment position deteriorates, since an increase in foreign debt generates an increase in number of contracts. However, with respect to the value of contracts concluded in a given year, none of the factors, apart from a minor impact of the rule of law, have a practical significance.

The conducted research and analysis of its results allowed identifying the following critical success factors of CSF for the PPP projects in Poland:

macroeconomic situation: GDP volume, public debt level, international investment position;

legal regulations: rule of law, corruption;

availability of financing: the level of private sector debt, bank assets and private sector credit debt in a given year.

Legal regulations and compliance with the rule of law, as well as the low level of corruption, have the greatest influence on success of the PPP. Among economic factors, the international investment position of the country, the level of banks' assets and private sector debt (calculated cumulatively) and its credit debt in a given year, are important.

\section{Conclusions}

When considering factors that determine the success of implementation of the PPP concept in the area of 
infrastructure, especially transport infrastructure, the main factors include: the macroeconomic situation, the wider rule of law and the availability of financing.

The most critical factors with the greatest impact on functioning and development of the PPP market in Poland are the legal framework, compliance with the rule of law and low levels of corruption. Results of research by Chou et al. [9] and Osei-Kyei and Chan [1] also show that these factors are fundamental for the PPP. Hammami et al. [10] emphasized that PPP is more common in countries where there are strong legal institutions and in countries where legal regulations well protect investors' rights. However, in the economic and financial aspect of the Polish economy, the size, internal market potential, as well as the international investment position of the country or the level of banks' assets, are very important. These factors were pointed out by Mansoor and Klein [13] and the team: Esmaeili, Pellicer and Molenaar [12]. Good macroeconomic conditions are able to attract investors and increase the possibility of obtaining funds. Therefore, the conducted research generally confirms the conclusions formulated earlier by other scientists. However, in Poland, deterioration of the international investment position, increase in the level of public and private sector debt contributes both to the increase in number of agreements concluded in a given year and their value. Based on that, it can be assumed that the
PPP projects in Poland are based, above all, on the longterm external (foreign) financing, both on the side of the public and private partner. However, as it has already been mentioned before, this hypothesis requires further, in-depth research.

The results presented are of practical and academic importance. In economic practice, the knowledge of the critical success factors of the PPP gives experts and institutions the opportunity to shape an effective, efficient policy for the implementation of the PPP enterprises. The results can also be incorporated into government guidelines to inform local practitioners about the best ways to manage projects. Assessment of the success factors at the initial stage is essential for both large transport infrastructure projects and provision of the transport services, for example by private operators in public transport.

From an academic point of view, it is worthwhile to expand the research to include further critical success factors, to conduct an in-depth analysis, using statistical methods and econometric models. The research could include such factors as: activity of advisory public agencies or, in relation to the private partner, activity of strong consortia. Another direction of research, even at the current stage of the CSF identification, using the adopted methodology, could be to increase its scale, e.g. by Central European countries (Slovakia, Czech Republic, Hungary) and to conduct comparative analysis.

\section{References}

[1] OSEI-KYEI, R., CHAN, A. Review of studies on the critical success factors for public-private partnership (PPP) projects from 1990 to 2013. International Journal of Project Management [online]. 2015, 33(6), p. 1335-1346. ISSN 0263-7863. Available from: https://doi.org/10.1016/j.ijproman.2015.02.008

[2] SAVAS, E. S. Privatizing the public sector: how to shrink government. New York: Chatham House, 1982. ISBN 978-0934540155.

[3] SAVAS, E. S. Privatization and public-private partnerships. New York: Chatham House, 2000. ISBN 978-1566430739.

[4] OSBORNE, D., GAEBLER, T. Reinventing government - how the entrepreneurial spirit is transforming the public sector. New York: Plume, 1993. ISBN 978-0452269422.

[5] GAYLE, D. J., GOODRICH, J. N. Privatisation and deregulation in global perspective. New York: Quorum Books, 1990. ISBN 0861871200.

[6] JACKSON, P., PRICE, C. Privatization and Regulation. A Review of the Issues. Longman Group Ltd., Essex, 1994.

[7] WALKER, C., SMITH, A. J. Privatized Infrastructure: The Build Operate Transfer Approach. Thomas Telford, London, 1995.

[8] ZAGOZDZON, B. Conditions for the development of public-private partnership PPP - analysis based on an example of transport infrastructure in Poland. Communications - Scientific Letters of the University of Zilina [online]. 2020, 22(1), p. 35-41. ISSN 1335-4205, eISSN 2585-7878. Available from: https://doi.org/10.26552/com.C.2020.1.35-41

[9] CHOU, J.-S., TSERNG, H. P., LIN, CH., YEH, CH.-P. Critical factors and risk allocation for PPP policy: Comparison between HSR and general infrastructure projects. Transport Policy [online]. 2012, 22, p. 36-48. ISSN 0967-070X. Available from: https://doi.org/10.1016/j.tranpol.2012.05.009

[10] HAMMAMI, M., RUHASHYANKIKO, J. F., YEHOUE, E. Determinants of public-private partnerships in infrastructure. IMF, Working Paper WP/06/99. IMF Institute, 2006.

[11] PARKER, D., HARTLEY, K. Transaction costs, relational contracting and public private partnerships: a case study of UK defence. Journal of Purchasing and Supply Management [online]. 2003, 3(9), p. 97-108. ISSN 1478-4092. Available from: https://doi.org/10.1016/S0969-7012(02)00035-7 
[12] ESMAEIli, B., PELLICER, E., MOLENAAR, K. R. Critical success factors for construction projects. In: Project Management and Engineering Research, 2014 [online]. MUNOZ, J. L. A., BLANCO, J. L. Y., CAPUZ-RIZO, S. F. (eds.). Cham: Springer, 2016. ISBN 978-3-319-26457-8, eISBN 978-3-319-26459-2. Available from: https://doi.org/10.1007/978-3319-26459-2

[13] MANSOOR, D., KLEIN, M. Government support to private infrastructure projects in emerging markets. Policy Research Working Paper, 1688. Washington: World Bank, 2007.

[14] BUTKIEWICZ, J., YANIKKAYA, H. The effects of IMF and World Bank lending on long-run economic growth: an empirical analysis. World Development [online]. 2005, 33(3), p. 371-391. ISSN 0305-750X. Available from: https://doi. org/10.1016/j.worlddev.2004.09.006

[15] Eurostat. European Commission [online]. Available from: https://ec.europa.eu/eurostat

[16] The WJP rule of law index 2009-2018 - World Justice Project, Washington, U.S.A., 2010-2019 [online]. Available from: https://worldjusticeproject.org

[17] Democracy index 2009-2018. A report by The Economist Intelligence Unit [online]. Available from: https://www.eiu.com/topic/democracy-index

[18] Corruption Perceptions Index 209-2018 - Transparency International [online]. Available from: https://www.transparency. org

[19] Single market scoreboard. Public procurement 2009-2018 - European Commission [online]. Available from: https://ec.europa.eu/internal_market/scoreboard 